\title{
The Effect of Papaya Leaf Flour and Turmeric Flour on theBroiler Carcasses
}

\author{
R. D. P. Sitanggang, S. Umar*, and N. Ginting \\ Animal Production Program Study, University of Sumatera Utara, Padang Bulan, Medan, Indonesia. \\ *Correspondent author: sayedumarfp@yahoo.com
}

\begin{abstract}
This study aims to determine the effect of providing papaya flour and turmeric flour as feed additives on slaughter weight, carcass weights and percentage of broiler chicken carcasses. This research was conducted in the enclosure of Animal Husbandry Study Program, Faculty of Agriculture, University of North Sumatra in October to November 2019. The design used in this study was a complete random design (CRD) with 4 treatments and 5 replications. The treatment consisted of $\mathrm{P} 0=$ control feed; $\mathrm{P} 1=$ addition of $0.5 \%$ turmeric flour; $\mathrm{P} 2$ = addition of $5 \%$ papaya leaf flour; and $\mathrm{P} 3=$ addition of $0.5 \%$ turmeric flour and $5 \%$ papaya leaf flour. The parameters observed were cutting weight, carcass weight and carcass percentage.

The results showed that the addition of turmeric feed and papaya leaves into the feed did not have a significant effect on the slaughter weight, carcass weight and percentage of 35-dayold broiler chicken carcass. The treatment showed a tendency that the weight of cut and carcass weight of papaya leaf addition was better than turmeric and control. The conclusion of this study is the addition of papaya leaf flour and turmeric flour as feed additives did not have an effect on the broiler chicken carcass.
\end{abstract}

Keywords: Papaya Leaves, Turmeric, Feed Additives, Carcasses, Broiler Chickens

Received [9 April 2020] | Revised [15 April 2020] |Accepted [21 April 2020]

\section{Introductions}

Broiler chicken is a meat-producing poultry as a source of animal protein to meet people's food needs. Broilers have a shorter production cycle compared to other poultry, because they have genetic traits that are better specifically for growth traits. Broiler business is a potential business to be developed as one of the sources of meat production in meeting the needs of animal protein for the people of Indonesia, which is increasing every year. In carrying out the business of broiler breeding there are several factors that influence the success of the feed (breeding), breeding (breeding), and governance (management) (Tiyono, 2011).

Along with the increasing number of broiler chicken needs that are increasingly in demand, improving the quality of broiler chicken feed by adding feed additives or feed additives to the basal feed is expected to improve the quality of broiler chicken products such as broiler chicken meat itself. One of the feed additives that are often found on the market is turmeric (Curcuma domestica). Kurkumin in turmeric has properties that can affect appetite as it can speed up the emptying of the stomach contents increased appetite and expedite expenditure 
bile, and this can increase the activity of the gastrointestinal tract (Purwanti, 2008). According Onyimonyi and Ernest (2009) flour papaya is one source of protein feed additives, because it has a crude protein content is high enough, namely $30,12 \%$. Besides papaya have benefits such as increased appetite and improve health. In papaya leaves, there are also many papain enzymes that have the ability to form new proteins, namely plastein and proteolytic enzymes, which can increase the efficiency of the digestive process.

\section{Materials and Methods}

The study was carried out in the enclosure of the Animal Husbandry Study Program, Faculty of Agriculture, University of North Sumatra, in October 2019, using 100-day-old broiler chickens (DOC) as many as 100 Cobb 500 strains from PT. Charoen Pokphand Jaya Farm and the duration of the study was 35 days and used a test cage measuring $0.5 \mathrm{~m}$ x $1 \mathrm{~m} \times 1 \mathrm{~m}$ as many as 20 pieces. Each cage is filled with 5 chickens, each cage is equipped with a place of food and drink and a 60-Watt incandescent lamp. Other equipment is a thermometer, rodalon, ND vaccine, and analytical scales. The ration used was its own composition ration.

Table 1. Starter Phase ration formulation

\begin{tabular}{lrrrr}
\hline \multirow{2}{*}{ Feed Ingredients (\%) } & \multicolumn{4}{c}{ Treatment } \\
\cline { 2 - 5 } & P0 & Q1 & P2 & Q3 \\
\hline Corn is smooth & 50,20 & 49,94 & 48,94 & 48,69 \\
Fine bran & 2 & 1,99 & 1,95 & 1,94 \\
Soybean meal & 34,50 & 34,32 & 33,63 & 33,46 \\
Fish flour & 6 & 5,97 & 5,85 & 5,82 \\
Coconut oil & 2 & 1,99 & 1,95 & 1,94 \\
Top mix & 1 & 0,99 & 0,97 & 0,97 \\
Coconut cake & 4,30 & 4,27 & 4,19 & 4,17 \\
Papaya leaves & 0 & 0 & 2,50 & 2,50 \\
Turmeric flour & 0 & 0,50 & 0 & 0,50 \\
\hline Total & 100 & 100 & 100 & 100 \\
\hline PK $(\%)$ & 24,18 & 24,12 & 24,10 & 24,04 \\
SK (\%) & 4,03 & 4,06 & 4,24 & 4,28 \\
LK (\%) & 3,60 & 3,59 & 3,57 & 3,56 \\
Ca (\%) & 0,96 & 0,95 & 0,96 & 0,95 \\
P (\%) & 0,59 & 0,59 & 0,58 & 0,59 \\
EM (Kcal/kg) & 2949,06 & 2950,54 & 2929,92 & 2931,41 \\
\hline Source: $*$ obtained based on calculations & \# Material feed as an additive to do the mixing
\end{tabular}


Table 2. Finisher Phase ration formulation

\begin{tabular}{|c|c|c|c|c|}
\hline \multirow{2}{*}{ Feed Ingredients (\%) } & \multicolumn{4}{|c|}{ Treatment } \\
\hline & P0 & Q1 & $\mathbf{P 2}$ & \\
\hline Corn is smooth & 64,8 & 64,47 & 63,18 & 62,85 \\
\hline Fine bran & 2,50 & 2,48 & 2,43 & 2,42 \\
\hline Soybean meal & 21,20 & 21,09 & 20,67 & 20,56 \\
\hline Fish flour & 6 & 5,97 & 5,85 & 5,82 \\
\hline Coconut oil & 2 & 1,99 & 1,95 & 1,94 \\
\hline Top mix & 1 & 0,99 & 0,97 & 0,97 \\
\hline Coconut cake & 2,50 & 2,48 & 2,43 & 2,42 \\
\hline Papaya leaves & 0 & 0 & 2,50 & 2,50 \\
\hline Turmeric flour & 0 & 0,50 & 0 & 0,50 \\
\hline Total & 100 & 100 & 100 & 100 \\
\hline PK $(\%)$ & 19,17 & 19,14 & 19,22 & 19,18 \\
\hline SK (\%) & 3,31 & 3,35 & 3,54 & 3,58 \\
\hline LK (\%) & 3,89 & 3,88 & 3,85 & 3,84 \\
\hline $\mathrm{Ca}(\%)$ & 0,91 & 0,91 & 0,92 & 0,91 \\
\hline $\mathrm{P}(\%)$ & 0,54 & 0,55 & 0,54 & 0,55 \\
\hline EM (Kcal/kg) & 3111,49 & 3112,16 & 3088,30 & 3088,98 \\
\hline
\end{tabular}

Source: * obtained based on calculations $\quad{ }^{\text {" }}$ Material feed as an additive to do the mixing

The study design used was a completely randomized design (CRD) consisting of 4 treatments and 5replications. Each treatment consisted of 5 chickens as follows:

P0: Ration without the addition of turmeric flour and papaya leaf flourP1: Ration with the addition of $0.5 \%$ turmeric flour

P2: Ration with the addition of 5\% papaya leaf flour

P3: Ration with the addition of $0.5 \%$ turmeric flour and $5 \%$ papaya leaf flour.

The parameters observed in this study include: 1 . Cut weight (g), obtained by weighing chicken after 12 hours of being satisfied; 2 . Carcass weight ( $\mathrm{g}$ ), which is obtained from the result of cutting after being separated from the head to the base of the neck, legs to the knee, fur, blood and the contents of the inner cavity except the kidneys and lungs; 3 . Percentage of carcass (\%), is the ratio of carcass weight and cut weight multiplied by $100 \%$.

Data obtained and analyzed by analysis of variance, if the data obtained are very real or real results then proceed with orthogonal contrast. 


\section{Results and Discussion}

Table 3. Average cutting weight, carcass weight and percentage of 35-day-old broiler chicken carcasses

\begin{tabular}{|c|c|c|c|c|c|}
\hline \multirow{2}{*}{ No. } & \multirow{2}{*}{ Parameter } & \multicolumn{4}{|c|}{ Treatment } \\
\hline & & P0 & Q1 & $\mathbf{P 2}$ & Q3 \\
\hline 1 & Cut Weight (g) & $\begin{array}{r}1745,73 \pm \\
156,27^{\mathrm{A}}\end{array}$ & $\begin{array}{r}1709,27 \pm \\
151,34^{\mathrm{A}}\end{array}$ & $\begin{array}{r}1861,33 \pm \\
64,48^{\mathrm{A}}\end{array}$ & $\begin{array}{r}1717,07 \pm \\
56,23^{\mathrm{A}}\end{array}$ \\
\hline 2 & Carcas Weight (g) & $\begin{array}{r}1215,53 \pm \\
176,38^{\mathrm{A}}\end{array}$ & $\begin{array}{r}1236,13 \pm \\
121,33^{\mathrm{A}}\end{array}$ & $\begin{array}{r}1328,40 \pm \\
45,75^{\mathrm{A}}\end{array}$ & $\begin{array}{r}1206,60 \pm \\
74,96^{\mathrm{A}}\end{array}$ \\
\hline 3 & $\begin{array}{l}\text { Percentage } \\
\text { carcass }(\%)\end{array}$ & $69,44 \pm 4,98^{\mathrm{A}}$ & $72,28 \pm 1,30^{\mathrm{A}}$ & $71,37 \pm 0,92^{\mathrm{A}}$ & $70,23 \pm 2,61^{\mathrm{A}}$ \\
\hline
\end{tabular}

Note: Superscripts in the same row and column show unreal differences $(\mathrm{P}>0,05)$

\subsection{Cut Weight}

Based on the results of the study, the highest average weight of 35 day broiler chickens was found in P2 (5\% addition of papaya leaves) in the amount of $1861.33 \mathrm{~g} /$ head and the lowest average weightin P1 (addition of $0.5 \%$ turmeric flour) was $1709,27 \mathrm{~g} /$ fish. From this study higher results were obtained when compared to the research of Setiawan and Sujana (2015) of $1606.67 \mathrm{~g} /$ head.

The results of the diversity analysis showed that the addition of papaya leaf flour and turmeric flour in the ration as feed additives gave no significant effect $(\mathrm{P}>0.05)$ on the slaughter weight of 35-day broilers. This is presumably because the active ingredients contained in turmeric flour and papayaleaf flour do not function well in spurring growth and also because the quality of the ration used is good so the effect of adding turmeric flour and papaya leaf flour as feed additives has not had a significant effect against broiler carcasses.

Parakkasi (1999) states that a food supplement is not an essential food ingredient when added to a commercial ration with a balanced nutritional content. Balitnak (1996) also states that the use of probiotics in the ration will affect if the quality of feed is low because the condition of the feed will affect the microflora in the digestive tract.

\subsection{Carcass Weight}

The results showed that the highest average yield of 35-day-old broiler chicken carcass was found in P2 treatment (addition of papaya leaf flour) in the amount of $1328.40 \mathrm{~g} /$ head, while the lowest average was in P3 treatment (addition of turmeric flour and papaya leaf flour) namely of 1206.60 $\mathrm{g} /$ head.

The results of the diversity analysis showed that the addition of turmeric flour and papaya leaf flour to the rations as feed additives had no significant effect $(\mathrm{P}>0.05)$ on the weight of the 35day-old broiler chicken carcass. Carcass weights in the study ranged from $1206.60 \mathrm{gr} /$ head - 
$1328.40 \mathrm{gr} /$ head with the percentage of carcasses ranging from $69.44 \%-72.28 \%$ and is still within the normalrange.

The treatment of feed additive P1, P2 and P3 has a carcass weight value that is almost the same as the control, this shows that the feed additive treatment did not have a negative impact. Factors affecting the percentage of carcass weight are the number and quality of rations. As well as several other factors namely body weight, fatness, gender and age. Cakra (1986) states that body organs such as legs, head, hair and internal organs can affect the weight of the carcass, the higher the weight of theorgan, the lower the weight of the carcass.

\subsection{Percentage of Carcass}

The percentage of carcasses in the results of the study showed that the highest average percentage of carcasses was in the treatment of P1 (addition of turmeric flour) in the amount of $72.28 \%$ and the lowest percentage of the carcass was in P0 (without treatment or control) that was $69.44 \%$. From the results of this study the percentage of carcasses ranged between $69.44 \%-72.28 \%$ and is still within the normal range. This is consistent with the statement of Bell Weaver (2002) who reported that the percentage of broiler carcasses varied between $65 \%-75 \%$ of live weight. This is also in line with the statement of Sumarni (2015) which states that the average percentage of broiler chicken carcassweight is $69.76 \%-73.39 \%$.

The results of the analysis of variance showed that the addition of turmeric flour and papaya leaf flour into the ration as a supplement to 35-day-old broiler chicken feed had no significant effect $(\mathrm{P}>0.05)$ on the percentage of carcasses.

This is suspected because the percentage of turmeric and papaya leaves that are too little or nooptimal so that it has not been able to have a significant impact on chicken weight gain, which is closely related to the percentage of carcasses and carcass weights. Budiansyah (2003) states that the percentage of carcass is not significantly different because the carcass weight is relatively equal and proportional to body weight gain. Almost the same final body weights will be in line to produce proportional carcass percentage so that the percentage of carcasses achieved is relatively the same.

Based on the results of the study it was also found that the largest average percentage of carcass was not produced from the weight of the largest carcass. This is thought to be influenced by the non-carcass weight of the animal and also because the animal deposited different proteins. This is in accordance with the statement of Maynard and Loosli (1969) which states that the increased proteincontent in carcasses and increased protein deposition are indicative of the process of utilizing feed protein. Positive protein deposition means that the animal uses proteins that live in the body toincrease body weight. 


\section{Conclusion}

From the results of the study, it was found that the addition of turmeric flour with a concentration of $0.5 \%$ and papaya leaf flour with a concentration of $5 \%$ as a feed additive did not influence the cutting weight, carcass weight and the percentage of broiler chicken carcasses aged 35 days and also had no negative effects.

\section{REFERENCES}

[1] Balitnak, 1996. Benefits of Starter Microbial (Pobiotik Starbio ) in Ruminant and Poultry Feed . Research and Agricultural Development News. RI DEPTAN. Vol. XVII No.4: 4- 5.

[2] Bell DD, Weafer WD. 2002. Commercial Chicken Meat and Egg Production. 5thedition. New York: Springer Science + Business. Inc. Spiring Street.

[3] Maynard, LA, and JK Loosli. 1969. Animal nutrition. 6th Ed., McGraw Hill Book Company, New Delhi.

[4] Onyimonyi, AE, and O. Ernest. 2009. An assessment of pawpaw leaf meal as protein ingredient for finishing broilers. Int. J. Poultry Sci., 8: 995-998.Purwanti. 2008. Study on the effectiveness of turmeric, garlic and zinc minerals on performance, fat content, cholesterol and health status of broilers. Thesis. Graduate School. Bogor Agricultural Institute.

[5] Rasyaf, M. 1997. Breeding Broiler. Self-help Spreaders. Jakarta.

[6] Setiadi, D., K. Nova and S. Tantalo. 2012. Comparison of Life Weight, Carcass, Giblet and Abdominal Fat of Medium Type Roosters with Different Strains that are given Commercial Broiler Rations. Faculty of Agriculture, University of Lampung, Lampung.

[7] Setiawan I, Sujana E. 2015. Final weight, percent of carcass tage and abdominal fat of broilers harvested at different ages. National Seminar of the Faculty of Animal Husbandry Unpad "Development of Production Systems and Utilization of Local Resources for Food Self-Reliance from Livestock" pp. 563-567. Bandung (ID): Padjadjaran University.

[8] Wahju, J. 2004. Poultry Nutrition Science. Fourth Printing. Gadjah Mada University Press. Yogyakarta. 